\title{
Development of snakes and ladders game (disaster response) as earthquake mitigation for children
}

\author{
Besse Nirmala, Andi Agusniatih, Haerul Annuar \\ Faculty of Teacher Training and Education, Early Childhood Education, Tadulako University, Indonesia \\ e-mail: bessenirmala@untad.ac.id
}

\section{Article History}

Submitted: November 18, 2020

Accepted: January 16, 2021

Published: January 27, 2021

DOI: 10.26555/jecce.v3i2.3111

\begin{abstract}
This study aims to produce of snakes and ladders game with feasible to increase understanding of children related to earthquake disaster mitigation. Snakes and ladders game will be applied to children aged 56 years in Palu city. This research is a research and development according to Borg and Gall. Data collection techniques using observation, interviews and questionnaries. Data analysis in the form of quantitative descriptive. The results showed that the assessment of the material validators get an average of 3.63 , media validators get an average of 3.8, and disaster validators get an average of 3.75 (feasible category). In the initial field trials, it averaged persentage $78 \%$ and was included in the feasible category. Operational field trials get an average persentage of $87 \%$ included in the feasible category. Comparative study results obtained sig. (2-tailed) of $0,000<0.05$, it can be concluded that $\mathrm{Ha}$ is accepted, which means that "there is a significant difference" between the average post-test results of the control group and the experimental group. The results obtained after applying the snake and ladder game, children can understand and carry out self-rescue activities when simulating an earthquake disaster.
\end{abstract}

Keywords : Snakes and Ladders Game, Earthquake Disaster Mitigation, Early Childhood

\section{Abstrak}

Penelitian ini bertujuan menghasilkan permainan ular tangga yang layak untuk meningkatkan pemahaman anak-anak terkait mitigasi bencana gempa bumi. Permainan ular tangga akan diterapkan pada anak usia 5-6 tahun di kota Palu. Penelitian ini merupakan penelitian dan pengembangan menurut Borg and Gall. Teknik pengumpulan data menggunakan observasi, wawancara dan kuisioner. Analisis data dalam bentuk deskriptif kuantitatif. Hasil penelitian menunjukkan bahwa penilaian validator materi mendapatkan rata-rata 3,63, validator media mendapatkan rata-rata 3,8, dan validator bencana mendapatkan ratarata 3,75 (kategori layak). Pada uji coba lapangan awal diperoleh ratarata persentase $78 \%$ dan termasuk dalam kategori layak. Uji coba lapangan operasional mendapatkan persentase rata-rata $87 \%$ termasuk dalam kategori layak. Hasil studi banding diperoleh sig. (2tailed) sebesar 0,000 <0,05 maka dapat disimpulkan bahwa "terdapat perbedaan yang signifikan" antara rata-rata hasil posttest kelompok kontrol dan kelompok eksperimen. Hasil yang diperoleh setelah diterapkan permainan ular tangga, anak dapat memahami dan melakukan kegiatan penyelamatan diri ketika melakukan simulasi bencana gempa.

Kata Kunci : Permainan Ular Tangga, Mitigasi Bencana Gempa Bumi, Anak Usia Dini. 


\section{INTRODUCTION}

Natural disasters are events that at any time can threaten and cause damage and casualties. One the natural disaster is an earthquake. The earthquake and tsunami that shaken up Palu, Sigi, and Donggala of Central Sulawesi on Friday, September 28, 2018 around 6.02 pm, not the first time in the history of disasters in the area. Palu is a disaster-prone point such as earthquake, tsunami, landslides, and liquefaction. Palu-Koro is the most active fault in Indonesia. According to ISDR (2004), a disaster is a serious disruption to the functioning of a community that results in widespread human, material, economic, or environmental harm that exceeds the ability of the affected community to cope with using their own resources. Disasters not only disrupt children's daily routines, but can also disrupt academic activities; lost social opportunities; and increased exposure to various life stressors (Anderson, 2005; Lopez et al., 2012; Mudavanhu et al., 2015; Peek \& Fothergill, 2014).

The victims most vulnerable to the impact of the earthquake are children, women and the elderly (Alston et al., 2019; Lopez et al., 2012). The importance of involving children in disaster mitigation education from an early age because children are the most vulnerable victims when a disaster occurs (Midtbust, Liv Gunvor Hove Dyregrov \& Djup, 2018). The analysis shows that most of the children do not have the right knowledge in dealing with disasters and mitigation methods (Tuladhar et al., 2014). One of the main factors why children included in the category of objects most vulnerable to disaster due to lack of access and opportunities in disaster mitigation (Vineeta \& Pathranarakul, 2019). The panic that occurs during a disaster and critical life after a disaster is very likely to be a traumatic condition in children, due to the child's limited understanding of the conditions that occur. The introduction of disaster mitigation in early childhood education is very appropriate because early childhood is at the peak of the golden age, where the construction of new concepts and knowledge of the disaster-based environment will enrich children's cognition. Currently, children's participation is of greater concern as a component of disaster risk reduction (Lopez et al., 2012). Children are highly competent and motivated to work together in planning, organizing and managing complex projects when they are directly involved. In turn, their involvement can further motivate them and reinforce skills development (Pfefferbaum et al., 2018; Wong et al., 2010).

This study aims to develop an educational game tool in this case the disaster response snake ladder game as earthquake disaster mitigation in children. This can build children's knowledge early on against the threat of disaster and how children are able to make decisions 
and act when disasters occur. These skills are designed for learning activities while playing that gives children the opportunity to do it on their own. The focus of the development of the game of snakes and ladders is earthquake mitigation. Although there is a lot of literature previously investigating the benefits of snakes and ladders in disaster mitigation (Purnamawati, 2020; Utami \& Mustari, 2020), to the best of researchers' knowledge, there is very little literature on the use of ladders in providing disaster mitigation against earthquakes. In this study, researchers addressed this literature gap by proposing the game of snakes and ladders as earthquake mitigation for early childhood.

Theoretical study, the development of the game of disaster response snake ladder as earthquake disaster mitigation is in line with the improvement of children's learning capacity through learning conditioning proposed by Gagne (Gredler, 2019). The design of learning for young children is prepared not only to provide learning direction that will be carried out but also to direct and stimulate child development tasks. Believes that full thematic development can be a framework for early childhood curriculum development and help the process of scaffolding in children (Wortham, 2006). Activities prepared by children can be directed to train and accustom children to be able to deal with conditions and situations that are traumatic and cannot, such as during a disaster. Play activities that conceptualize certain conditions such as disasters will build new knowledge and contract the attitudes and actions needed when a disaster occurs.

\section{METHOD}

The present study was categorized a research and development with procedures adapted from Borg and Gall 1989 (Syaodih Sukmadinata, 2007). This model was chosen because it has the advantage of being simpler and systematically structured. This research uses quasiexperimental. Quasi-experimental research is research that resembles experimental research but not actual experimental research. Quasi-experimental research conducted on the same sample and provide manipulation of the measured variables. In this study the design used is pretest and post-test. The pre-test and post-test results aim at formulating the final conclusions of the development of the snakes ladders game as earthquake disaster mitigation. The population of the present study involved kindergarten in Palu city. 
The data of the study were quantitatively analyzed using some test, namely validity test, reliability test, normality test, and hypothesis test using t-test where the average score of implementation before and after using snakes and ladders game.

The research location is determined through purposive sampling supported by theoretical sampling. The choice of location by purposive sampling means that the location of the study has been determined from the beginning based on the characteristics of needs, namely an area prone to earthquake disasters. The early childhood education selected for the implementation testing activities took place at IT Pelita Hati Kindergarten, Putra Kaili Permata Bangsa Kindergarten, Khalifah Kindergarten, and Mutiara Hati Kindergarten. This research was conducted in March to October 2019.

The number of subjects involved in this study are as follows. Limited field trials involving 4 children, wider field trials involving 8 children, operational field trials involving 20 children, and tests of 20 children.

This research and development procedure is adapted from the Borg and Gall development model. The development procedures are shown at figure 1.

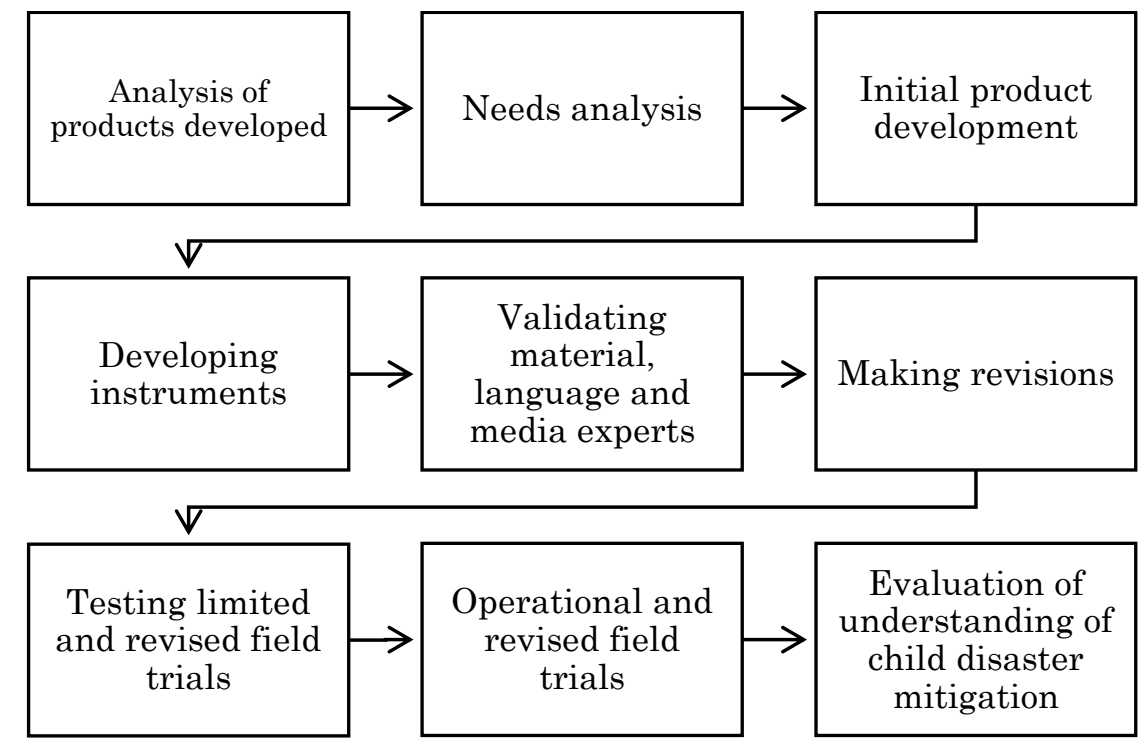

Figure 1. Development Research Procedure Scheme adapted from Borg and Gall 1989 (Sukmadinata, 2012:169-170).

Data obtained from the results of the feasibility trial were collected through observation, interview and documentation techniques and the pretest posttest to see children's understanding of earthquake disaster mitigation. The results obtained after applying the snake 
and ladder game, children can understand and carry out self-rescue activities when simulating an earthquake disaster.

Data from the results of the feasibility trial were analyzed using the conversion of quantitative data to qualitative data. Table 1 is a reference table assessing the data generated from media experts and material experts. If the learning media for the game of snakes and ladders for disaster response has been revised and has been recognized for its feasibility in terms of media experts and material experts, it can be tested on children. This is done so that the media developed is feasible and of good quality to be applied. The conversion of likert scale are shown at table 1.

Table 1. Conversion of Likert Scale Scores on the Media Feasibility Level

\begin{tabular}{lll}
\hline The Range & Criteria & Feasibility Level \\
\hline $\bar{X}>4,08$ & Very good & Feasible \\
\hline $3,36<\bar{X} \leq 4,08$ & Good & \\
\hline $2,64<\bar{X} \leq 3,35$ & Enough & Not feasible \\
\hline $1,92<\bar{X} \leq 2,63$ & Less & \\
\hline $\bar{X} \leq 1,92$ & Very Less &
\end{tabular}

(Source: Sugiyono, 2012)

\section{RESULTS AND DISCUSSION}

Data and information are obtained through preliminary studies, limited field trials, wide field trials, and operational field trials. The presentation of the results of the study is as follows.

\section{Preliminary Study Results}

There are several themes that exist in early childhood institutions related to the insight of disaster, namely the universe, water, air and fire. However, the teacher never gives an understanding related to earthquake disaster mitigation through game. Introduction to the concept of a broad disaster and not accompanied by activities to extract attitudes and skills before, during and after a disaster occurs because teachers do not have and understand knowledge about disaster mitigation.

\section{Initial Product Development}

The results of the initial product development of the disaster response snake ladder game are shown at table 2 . 
Table 2. Snakes and Ladders Game

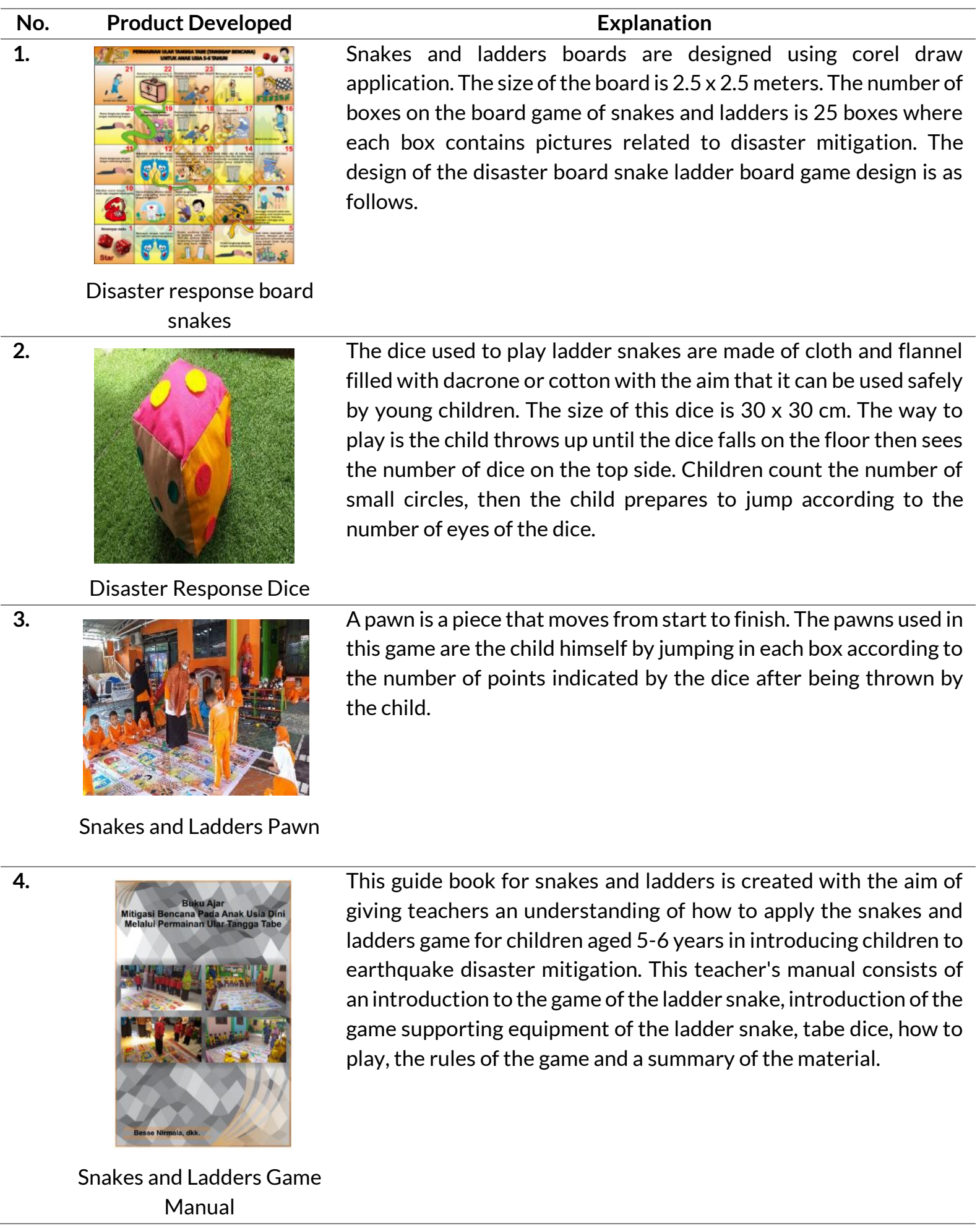

\section{Validation Results}

After the results of the initial product development, a feasibility test will be conducted by experts in the material, language and media. Material expert validation was done once. The 
validation results obtained a mean score of 3.63 with decent criteria. Suggestions from material expert validators are that the material in each box is adjusted to the characteristic of early childhood, brief and easy to understand. Language expert validation of linguist is done once. The validation result is obtained a mean score of 3.8 with reasonable criteria. Suggestion from a linguist validator that there is a typing error in box 14 and needs to be corrected immediately. The validation of the media expert was carried out three times. The results of the validation of media expert got a mean score of 3.75 with the criteria worth testing. The suggestion from the media validator is that the dice are made rather large and lightweight so that they are easy to use by children and the image does not dominate the writing so that it is easy to read.

\section{Trials and Revision}

Limited field trials by implementing a disaster response snake ladder game involving four children in IT Pelita Hati Kindergarten. These four children have different levels of cognition, namely high, medium and low levels of cognition. The results of limited field trials obtained an average of 3.40 with reasonable criteria.

Based on the results of limited field trials stated that the disaster response snake ladder game meets the feasibility aspects. However, when field trials are limited in terms of companions, there needs to be a revision, namely teachers have difficulty managing children because some children cannot wait to turn to roll the dice. There are things that need to be improved in this game of snakes and ladders, namely in terms of material it needs to be examined again. The language used is in accordance with the characteristics of the child and is not too long so that it is easily understood by the child. Then the pictures made are adjusted to the questions or statements on the material. The dice that are made must be safe and strong when used by children and larger in size and made as attractive as possible with color combinations that match the characteristics of early childhood.

Broader field trials involved eight children in the Putra Kaili Permata Bangsa Kindergarten who were selected from different levels of cognition. Children are divided into two groups, each group consisting of two children as the opponent and friend. The results of wider field trials obtained an average of 3.75 with decent criteria. Based on the results of wider field trials, it was stated that the snake ladder game of disaster response fulfills the feasibility aspect. Therefore, at this stage the researcher did not revise the snakes and ladders game. 
The operational field trials involved 20 children in the Khalifah Kindergarten who were selected from different levels of cognition. When implementing the disaster response snake ladder game, 20 children were divided into 4 groups. The results of operational trials obtained an average of 3, 90 with very decent criteria. Based on the results of a series of field trials related to the game of disaster response snake ladder, it was stated that the game was suitable for use by early childhood as earthquake disaster mitigation in the city of Palu. The field trials process are shown at table 3.

Table 3. Field Trials Process

\begin{tabular}{ll}
\hline IMPLEMENTATION OF SNAKES AND LADDERS & \multicolumn{1}{c}{ RESULT OF RESEARCH } \\
The results of the practical analysis (feasibility) of \\
the Tabe and Ladder snake game media as \\
earthquake mitigation for children aged 5-6 years \\
in Palu City for each observation indicator has an \\
average of 3.04 or is in the "implemented" \\
category. The results of the feasibility analysis of \\
the Tabe and Ladder snake game as earthquake \\
mitigation for each observation aspect have an \\
average of 3.63 or are in the "feasible" category.
\end{tabular}

Pelita Hati IT Kindergarten

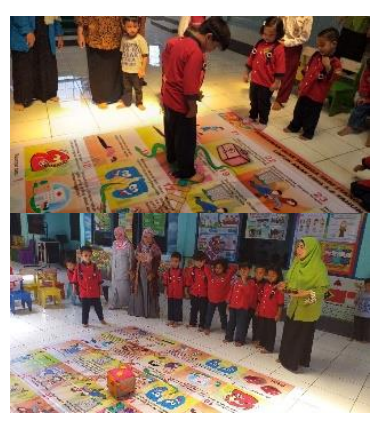

Permata Bangsa Kindergarten
The results of the analysis of the practicality (implementation) of the Tabe ladder snake game as disaster mitigation for children aged 5-6 years for each aspect of the observation have an average of 3.54 or are in the "implemented" category. The results of the feasibility analysis of the Tabe and Ladder snake game for each observation aspect have an average of 3.8 or are in the "feasible" category.

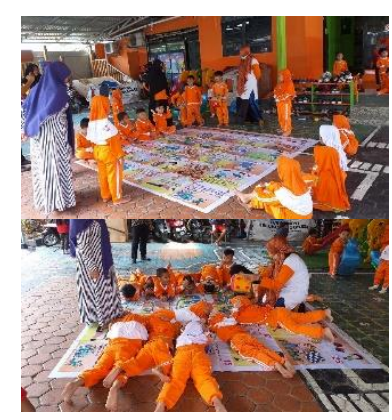

Khalifah Kindergarten
The results of the analysis of the practicality (feasibility) of the Tabe ladder snake game as disaster mitigation for children aged 5-6 years for each observation aspect have an average of 4.1 or are in the "implemented" category. The results of the feasibility analysis of the Tabe and Ladder snake game for each observation aspect have an average of 3.9 or are in the "feasible" category. 


\section{Comparative Study Outcomes}

Researchers used test instruments to obtain data on children's knowledge related to earthquake disaster mitigation. The technique used is to compare the learning outcomes of children who do not use the snake ladder game disaster response with the learning outcomes of children who have used the ladder snake game. The kindergarden involved were Khalifah kindergarden as the experimental group and Mutiara Hati kindergarden as the control group.

The effectiveness test uses a t-test that compares the average results of pre-test and posttest. Data Processing using SPSS 22 with the independent samples test formula which is a different test of the same two samples but get different treatments. The steps taken to process the t-test data before processing the data are compiling a hypothesis. The hypothesis in this study are, Ho: there is no difference in the average pre-test and post-test result; and $\mathrm{H} 1$ results: there are differences in the average pre-test and post-test results. Independent samples test are shown at table 4.

\begin{tabular}{|c|c|c|c|c|c|c|c|c|c|c|}
\hline \multicolumn{11}{|c|}{ Table 4. Independent Samples Test } \\
\hline & & \multicolumn{2}{|c|}{$\begin{array}{l}\text { Levene's } \\
\text { Test for } \\
\text { Equality of } \\
\text { Variances }\end{array}$} & \multicolumn{7}{|c|}{ t-test for Equality of Means } \\
\hline & & \multirow[t]{2}{*}{$\mathrm{F}$} & \multirow[t]{2}{*}{ Sig. } & \multirow[t]{2}{*}{$\mathrm{t}$} & \multirow[t]{2}{*}{ df } & \multirow[t]{2}{*}{$\begin{array}{l}\text { Sig. (2- } \\
\text { tailed) }\end{array}$} & \multirow[t]{2}{*}{$\begin{array}{l}\text { Mean } \\
\text { Differe } \\
\text { nce }\end{array}$} & \multirow{2}{*}{$\begin{array}{l}\text { Std. } \\
\text { Err } \\
\text { or } \\
\text { Diff } \\
\text { ere } \\
\text { nce }\end{array}$} & \multicolumn{2}{|c|}{$\begin{array}{l}95 \% \text { Confidence } \\
\text { Interval of the } \\
\text { Difference }\end{array}$} \\
\hline & & & & & & & & & Lower & Upper \\
\hline \multirow[t]{2}{*}{ Value } & $\begin{array}{l}\text { Equal } \\
\text { variances } \\
\text { assumed }\end{array}$ & $\begin{array}{l}1.02 \\
3\end{array}$ & $\begin{array}{l}.31 \\
8\end{array}$ & $\begin{array}{l}- \\
21.025\end{array}$ & 38 & .000 & $\begin{array}{l}- \\
25.500 \\
00\end{array}$ & $\begin{array}{l}1.2 \\
128 \\
7\end{array}$ & $\begin{array}{l}- \\
27.955 \\
33\end{array}$ & $\begin{array}{l}- \\
23.0446 \\
7\end{array}$ \\
\hline & $\begin{array}{l}\text { Equal } \\
\text { variances } \\
\text { not } \\
\text { assumed }\end{array}$ & & & $\begin{array}{l}- \\
21.025\end{array}$ & 35.604 & .000 & $\begin{array}{l}- \\
25.500 \\
00\end{array}$ & $\begin{array}{l}1.2 \\
128 \\
7\end{array}$ & $\begin{array}{l}- \\
27.960 \\
76\end{array}$ & $\begin{array}{l}- \\
23.0392 \\
4\end{array}$ \\
\hline
\end{tabular}

Based on the result of the independent samples test, it was found that the tcount was 21.025 with the significance value of $0,000<0.05$, it can be concluded that $\mathrm{H} 1$ was accepted, which means that "there is a significant difference" between the average results of the control group post-test with the experimental group.

There are several feasibility tests undertaken to obtain assessments, criticisms, comments, and suggestions, so that the game of disaster ladder snakes can be said to be feasible. 
The feasibility tests undertaken include validation of material experts, linguists, media experts, limited field trials, wider field trials, and operational field tests.

The results showed that respondents' assessment of the developed disaster response snake ladder game, in general respondents rated good. The results of the questionnaire related to the feasibility of the disaster response snake ladder game that has an average of 3.8 with decent criteria. Participatory techniques, such as the snake and ladder game played by children in which there are activities to investigate and discuss natural risks with peers, not only results in increased knowladge but also the introduction of disaster mitigation measures (Ronan et al., 2016; Widowati et al., 2020; Winarni \& Purwandari, 2018).

Based on the results of these studies in accordance with the opinion of (Rifa, 2012; Utami $\&$ Mustari, 2020) that the benefits of snakes and ladders game in general are providing knowledge to children through the process of learning to play while learning, stimulating the development of thinking, creativity, and language, creating a play environment that interesting, providing a sense of security and fun, as well as improving the quality of children's learning in physical motor development, language, social emotional, and art. Snake Games stairs contain important elements related to child disaster education, in context protect children from violence and bullying effective in increasing children's knowledge by up to 150\% (Widowati et al., 2019). Some of the most recent research results focus on children who have experienced a disaster, understand their perceptions and make recovery through art activities, music, games, photography, vidiography, and other (Fletcher et al., 2016; Freeman et al., 2015).

Judging from the colors used in the disaster response snake ladder game using a variety of color compositions and classified as bright in order to attract the attention of children. Judging from the presence of images in the game, these images are animated images that are tailored to the characteristics of early childhood. It is intended that the emotional closeness of children according to the character of the picture. In addition, in this snakes and ladders game, children use a simulation method on how to save themselves from the earthquake disaster. This is supported by a statement by (Steward \& Wan, 2007) in his research on the role of simulation in disaster management to measure someone's readiness in facing disasters. Then according to (Olson et al., 2010) in his research also stated that education about disaster preparedness using simulation in the form of games can give better results that those who do not use simulation. 


\section{CONCLUSION}

The disaster response snake ladder game was developed using the R\&D research stages of the Borg \& Gall model by following the ten stages of development. The results of the initial field trial involving 4 children in IT Pelita Hati Kindergarten by obtaining an average result of 3.40 with the criteria of "feasible". Then the main field trials involving 8 children obtained an average of 3.75 with the criteria of "feasible", and an operational field trial involving 20 children obtained an average of 3.9 with the eligibility criteria. Comparative study results obtained sig. (2-tailed) of $0,000<0.05$, it can be concluded that $\mathrm{Ha}$ is accepted, which means that "there is a significant difference" between the average post-test results of the control group and the experimental group.

Based on the results of the research that has been done, we recommend some suggestions. The next researcher or developer is expected to be able to develop more models of disaster mitigation or child preparedness in facing disasters so the teachers can implement the learning process in a number of themes in kindergarten institutions. For teaching staff /teachers, it is expected to be able to use and utilize learning media, namely the snake ladder game of disaster response in the learning process in class so that children get knowledge related to disaster mitigation. At last for children, it is hoped that the game of snakes and ladders can be used and utilized well for fun play activities.

\section{REFERENCES}

Alston, M., Hazeleger, T., \& Hargreaves, D. (2019). Social Work and Disasters A Handbook for Practice(1st ed.). Routledge.

Anderson, A. W. (2005). Bringing Children into Focus on the Social Science Disaster Research Agenda. International Journal of Mass Emergencies and Disasters, 23(3), 159-175.

Cox, R. S., Scannell, L., Heykoop, C., Tobin-Gurley, J., \& Peek, L. (2017). Understanding youth disaster recovery: The vital role of people, places, and activities. International Journal of Disaster Risk Reduction, 22, 249-256. doi.org/10.1016/j.ijdrr.2017.03.011

Fletcher, S., Cox, R. S., Scannell, L., Cheryl, H., Peek, L., \& Tobin-Gurley, J. (2016). Youth Creating Disaster Recovery and Resilience: A Multi-Site Arts-Based Youth Engagement 
Research Project. Children, Youth and Environments, 26(1), 148-163. https://doi.org/doi.org/10.7721/chilyoutenvi.26.1.0148

Freeman, C., Nairn, K., \& Gollop, M. (2015). Disaster impact and recovery: what children and young people can tell us. Kōtuitui: New Zealand Journal of Social Sciences Online, 102), 103-115. https://doi.org/10.1080/1177083X.2015.1066400

Gredler, M. E. (2019). Learning and Instruction Teori dan Aplikasi Edisi Keenam. 170-172.

Lopez, Y., Hayden, J., Cologon, K., \& Hadley, F. (2012). Child participation and disaster risk reduction. International Journal of Early Years Education, 20(3), 300-308. https://doi.org/10.1080/09669760.2012.716712

Midtbust, Liv Gunvor Hove Dyregrov, A., \& Djup, H. W. (2018). Communicating with children and adolescentsabout the risk of natural disasters. European Journal of Psychotraumatology, 92), 1-10. https://doi.org/10.1080/20008198.2018.1429771

Mudavanhu, C., Manyena, S. B., Collins, A. E., Bongo, P., Mavhura, E., \& Manatsa, D. (2015). Taking Children's Voices in Disaster Risk Reduction a Step Forward. International Journal of Disaster Risk Science, 6(3), 267-281. https://doi.org/10.1007/s13753-015-0060-7

Olson, D. K., Scheller, A., \& Wey, A. (2010). Using gaming simulation to evaluate bioterrorism and emergency readiness training. Journal of Public Health Management and Practice, 205), 468-477. https://doi.org/10.1177/003335491012500316

Peek, L., \& Fothergill, A. (2014). Post-Disaster Decline: Understanding Children's Vulnerability Before, During, and After Katrina. A Quarterly Technical Assistance Journal on Disaster Behavioral Health, 103), 1-4.

Pfefferbaum, B., Pfefferbaum, R. L., \& Van Horn, R. L. (2018). Involving children in disaster risk reduction: the importance of participation. European Journal of Psychotraumatology, q2), 1-6. https://doi.org/10.1080/20008198.2018.1425577

Purnamawati, I. G. A. A. (2020). Pengaruh Pemberian Edukasi dengan Media Permainan Ular Tangga terhadap Kesiapsiagaan Anak Sekolah Dasar dalam Menghadapi Bencana Gempa Bumi. Poltekkes Kemenkes Denpasar.

Rifa, I. (2012). Koleksi Games Edukatif di Dalam dan Luar Sekolah(1st ed.). Flashbooks. 
Ronan, K. R., Haynes, K., Towers, B., Alisic, E., Ireland, N., Amri, A., Davie, S., \& Petal, M. (2016). Child-centred disaster risk reduction: Can disaster resilience programs reduce risk and increase the resilience of children and households? Australian Journal of Emergency Management, 31(3), 49-58. (DOI TIDAK DITEMUKAN)

Steward, D., \& Wan, T. (2007). The role of simulation and modeling in disaster management. Journal of Medical Systems, 31(2), 125-130. https://doi.org/10.1007/s10916-0069047-7

Syaodih Sukmadinata, N. (2007). Metode Penelitian Pendidikan. Bandung: Remaja Rosda Karya, 169-170.

Vineeta, T., \& Pathranarakul, P. (2019). Gender inclusiveness in disaster risk governance for sustainable recovery of 2015 Gorkha Earthquake, Nepal. International Journal of Disaster Risk Reduction, 34, 209-219. https://doi.org/10.1016/j.ijdrr.2018.11.019

Tuladhar, G., Yatabe, R., Dahal, R. K., \& Bhandary, N. P. (2014). Knowledge of disaster risk reduction among school students in Nepal. Geomatics, Natural Hazards and Risk, 5(4), 190-207. https://doi.org/10.1080/19475705.2013.809556

Utami, S. D., \& Mustari, H. (2020). PERUT SINCAN (Snakes and Ladders Game of Disaster Mitigation) as a Disaster Education Learning Medium. Jurnal UNS: Social, Humanities, and Education Studies (SHEs): Conference Series, 3(1), 76-82. https://doi.org/10.20961/shes.v3i1.45015

Widowati, E., Hendriyani, R., \& Nugroho, E. (2019). Development of Child Friendly Educative Game Model As Method to Prevent Violence Against Children in School. KnE Social Sciences, 3(18), 167-176. https://doi.org/10.18502/kss.v3i18.4710

Widowati, E., Sugiharto, S., Wahyuningsih, A. S., Husodo, A. H., \& Istiono, W. (2020). Transformation Prospect of a Non Disaster-Prepared-School in Implementing Management of Child Safety Education. Unnes Journal of Public Health, 91), 34-42. https://doi.org/10.15294/ujph.v9i1.34378

Winarni, E. W., \& Purwandari, E. P. (2018). Disaster Risk Reduction for Earthquake Using Mobile Learning Application to Improve the Students Understanding in Elementary School. 
Mediterranean Journal of Social Sciences, 92), 205-214. https://doi.org/10.2478/mjss-2018-0040

Wong, N. T., Zimmerman, M. A., \& Parker, E. A. (2010). A typology of youth participation and empowerment for child and adolescent health promotion. American Journal of Community Psychology, 46(1), 100-114. https://doi.org/10.1007/s10464-0109330-0

Wortham, S. C. (2006). Early childhood curriculum: Developmental bases for learning and teaching. Kevin M. Davis. 